\title{
Temporal variation and cross-sectional differences of accounting conservatism in emerging countries
}

\author{
Maha Khalifa $^{\mathrm{a}}$, Hakim Ben Othmen ${ }^{\mathrm{b}}$, Khaled Husseiney ${ }^{\mathrm{c}}$ \\ ${ }^{a}$ University of Manouba,17 impasse Bech Chedly, Corniche Bizerte 7000, Tunisia \\ ${ }^{b}$ University of Manouba, Adress: TunisBusiness School, Office $N^{\circ} 1-12$, El mourouj 2074, Tunisia \\ ${ }^{c}$ Plymouth Business School University of Plymouth 405H Cookworthy BuildingPlymouth PLA 8AAUnited Kingdom
}

\begin{abstract}
Prior research reported that accounting conservatism has increased over time in developed countries. In this paper, we try to examine the time-series extent and shift of accounting conservatism in emerging countries over the period 2000-2012. We also analyze differences in conservatism level across countries, regions, legal regimes and industries and the effect of size, Market-to-Book and leverage on the degree of conservatism. We use a set of measures to assess the degree of conservatism. These include changing time-series properties of profitability, earnings, cash flows, accruals components, asymmetric timeliness, Market-to-Book ratio. We find that the degree of conservatism is declined during the period between 2000 and 2007 and increased over the period 2007-2012. In addition, we observe significant differences in accounting conservatism between countries, across regions and industries.
\end{abstract}

Keywords:Conservatism, Loss frequency, Earnings, Accruals, Market-to-Book, Emerging Markets, Time variation, Cross-section differences

\section{Introduction:}

Accounting conservatism is considered as one of the most important attribute of financial reporting and it has influenced accounting practice for at least five centuries (Basu, 1997; Watts, 2003a). Watts (2003a) argue that accounting practice is not only conservative, but it has become more and more conservative in the last 30 years. If the demand of conservatism has increased over time, the analysis of time-series financial statement needs to be adjusted in order to obtain more reliable interpretation of accounting numbers (Givoly and Hayn, 2000).

Previous studies have tried to define, measure conservatism and explain the reasons behind its existence (Basu, 1997; Givoly and Hayn, 2000; Watts, 2003a; Watts, 2003b). According to them, conservatism can be of two types: conditional and unconditional. Conditional conservatism is defined as "the accountants' tendency to require a higher degree of verification for recognizing good news than bad news in financial statements" Basu (1997, p7). However, unconditional conservatism is defined as: "the on average understatement of the book value of net assets relative to their market value" Beaver and Ryan (2005, p269). The first type of conservatism is mainly related to the understatement of profits; however the second type is more related to the understatement of assets. In detail, when conservatism (both types) is set off, many implications arise. In fact, the presence of conservatism results in lower cumulative net income and assets values (Mason, 2004). In future periods, conservatism will induce an increase (decrease) in loss frequency (profitability) (Givoly and Hayn; 2000, Khan and Watts, 2009) by deferring the recognition of positive economic events until their effective realization, while negative economic events are immediately recognized to anticipate any future bad news. Roychowdhury and Watts (2007) point out that when asymmetric recognition of bad news vs. good news is observed cumulatively over long periods, the market value of equity will be overstated relative to the book value of equity, thus conditional conservatism leads to an understatement of assets value and overstatement of liabilities over time.

In this sense, studying the level and the extent of accounting conservatism becomes an important task in accounting research. Lai et al. (2012) denoted that understanding the shift and the trend in conservatism may have implications on financial statement analysis. In the same vein, Givoly and Hayn (2000) stated that if the degree of conservatism increases over time, a time-series analysis of financial statement should take in account the conservative characteristic by making adjustment for the varying level of conservatism in order to obtain more reliable analysis of accounting numbers. They also argued that understanding the time-series change in earnings, cash flows and accruals component is important for investors, researchers, auditors and regulatory bodies. For example, Basu (1997) stated that auditors will support more legal liability if recognition of bad news is late. Therefore, be aware of changes in conservatism level will help auditors to face their legal liability (Basu, 1997; Watts, 2003a). Prior studies supported the idea that accounting conservatism has increased over time in the context of developed countries. Givoly and Hayn (2000) studied the time-series change in accounting conservatism 
by examining the changing time-series properties of earnings, cash flows and accruals by using four different measures of accounting conservatism. They reported that companies from US exhibit an increased level of conservative financial reporting over time especially during the period between 1950 and 1998. However Grambovas et al. (2006) found that conservatism has increased in European countries from 1989 to 1998 and declined both in US and Europe over the period 1998-2004. In other context, Lai et al. (2012) concluded that the degree of conservatism in Australia fluctuates without any obvious trend over the 17-year period from 1993 to 2009. Other studies have focused on international differences in accounting conservatism. For example, Gassen et al. (2013) reported that common law countries are likely to exhibit more conservative financial statements than code law countries. Their results coincide with earlier work initiated by Ball et al. (2000) who also found that the level of conservatism is higher in common law than in code law countries.

The objective of this paper is two-fold. First, we try to examine the time-series variation of accounting conservatism in developing markets including 47 countries belong to emerging and frontier emerging markets over the period of 2000 to 2012. Second we analyze the cross-sectional differences in the level of conservatism among different emerging regions, industries and legal regimes (common law and civil law). Our work is motivated by many reasons. First, to the best of our knowledge, no previous studies have examined the temporal variation of conservatism in emerging markets. Second, emerging market have recognized in last decade an economic and financial upheaval (crisis) which may rendered many businesses, accounts and auditors extremely prudent (conservative) in order to face any allegation, embezzlement or other misuses resources. Third, emerging markets have different institutional factors comparing to developed countries which means that the demand of conservatism according to taxation, litigation, regulation and contracting factors (Watts, 2003a) can be different from that in US and EU countries. Thus, the results of studying the trend and the extent of conservatism may different in emerging markets comparing to developed countries.

We offered several novel contributions to existing literature. Following the same approach adopted by Givoly and Hayn (2000) and Lai et all (2012), we use four measures of conservatism: (1) loss frequency and profitability (Return-on-Asset), (2) distribution of cash flows and accruals, (3) market-to-Book ratio, (4) The Basu (1997) measure of timeliness to assess the time varying of the degree of conservatism over time. We find that the level of conservatism according to the profitability measure (ROA) has decreased from 2000 to 2007 and has increased during the period between 2007 and 2012. We find also the same result using the Market-to-Book ratio as a measure of unconditional conservatism. With regard to the distribution of accruals, we report a negative accumulation of non-operating accruals which is more pronounced in the period of 2007 to 2012.

Our study contributes to existing literature by examining also the cross-regions differences in the level of conservatism. We find that firms belong to countries from East Europe exhibit more conservatism than those from Asia and MENA/Africa countries. However, American countries firms do not produce conservatism earnings compared with firms from the other regions.

The remainder of the paper is organized as follows. Section 2 presents definitions of conservatism and how it can be measured. Section 3 presents our research design including sample selection, emerging market characteristics and variables measures. Section 4 shows the findings related to conservatism's time varying. Findings related to the cross-sectional differences in conservatism are discussed in section5. Section 6 concludes.

\section{Conservatism measures}

Conservatism has been viewed as one of the most important attributes of financial reporting and has been used over other accounting principles such as historical cost and realization conventions for centuries (Basu, 1997; Chan et al. 2009). Basu's (1997, p. 7) defined conservatism as: "the accountant's tendency to require a higher degree of verification for recognizing good news as gains than to recognize bad news as losses". Under this interpretation, earnings will reflect bad news more quickly than good news. Beaver and Ryan (2005, p269) defined accounting conservatism as "the on average understatement of the book value of net assets relative to their market value". Under this interpretation, conservatism will lead to the understatement of net assets comparing to their market value. Givoly and Hayn (2000, p292) argued that "conservatism is a selection criterion between accounting principles that leads to the minimization of cumulative reported earnings by slower revenue recognition, faster expense recognition, lower asset valuation, and higher liability valuation". The first consequence of conservatism is that the observed number of losses wil increase in time which means that the pourcentage of firms that report negative income will increase from year to year (Givoly and Hayn, 2000; Balkrishna et al., 2007; Khan and Watts, 2009). In the same sense, in period of conservatism the profitability as measured by ROA should increase over time. Another consequence of conservatism is that accruals tend to reverse (Givoly and Hyan, 2000). Indeed, 
during the period in which net income exceeds cash flows from operations, the accruals tend to be negative and when net income falls below cash flows, accruals take positive sign. Therefore another measure of conservatism is the sign of and the magnitude of cumulative accruals. Persistence of negative accruals is a sign of conservatism practices. In detail, accruals (TOACC) are decomposed into operating accruals (OPACC) and non-operating accruals (NOPACC). Basu (1997), Givoly and Hayn (2000) and Watts (2003b) argued that the first, the second and the third moment of the distribution of TOACC and NOPACC vary with conservatism. In addition to those measures, Givoly and Hayn (2000) used the skewness of earning distributions.

The common used measure of conservatism was proposed by Basu (1997). Despite the criticism about this measure, it still widely used in accounting literature. Basu (1997) measured conditional conservatism using a reversal regression model which relates earnings to the return. The model is as follows:

$$
E A R_{i}=\beta_{0}+\beta_{1} D R_{i}+\beta_{2} R E T_{i}+\beta_{3} D R_{i} * R E T_{i}+\varepsilon_{i}
$$

Where $\mathrm{i}$ indexes the firm, EAR is earnings, RET is the return of firrm $i$ over the 12 months beginning nine months prior to the end of fiscal year $t$, DR is a dummy variable equal to 1 when RET $>0$ and equal to 0 otherwise, and $\varepsilon_{i}$ is the residual. According to Basu (1997), the magnitude of the coefficient on positive returns, $\beta_{1}$, relates to the incremental response of accounting earnings to good news. Similarly, the degree of which bad news was impounded in earnings is measured by $\beta_{2}+\beta_{3}$ and where $\beta_{3}$ and the total bad news timeliness. According to Basu (1997), if conservatism exists, $\beta_{3}$ should be significant and positive. Givoly and Hayn (2000) added another measure which is the relative sensitivity of earnings to bad news compared with their sensitivity to good news and which is measured by the ratio $\left(\beta_{2}+\beta_{3}\right) / \beta_{2}$. In period of conservatism, this ratio should be greater than 1 . However, the estimation value of the coefficient $\beta_{2}$ sometimes is close or below to zero, which can affect the interpretation of this ratio. For this reason, Gassen et al. (2013) have modified this ratio using trigonometric concept. The modified ratio is given by:

$$
B A S U=\operatorname{Arctang}\left(\beta_{2}+\beta_{3}\right)-\operatorname{Arctang}\left(\beta_{2}\right)
$$

We adopt this measure as an alternative to the ratio $\left(\beta_{2}+\beta_{3}\right) / \beta_{2}$. The greater (lower) value of BASU the greater (lower) the level of conservatismIn conclusion, following Givoly and Hayn (2000) and Lai et al. (2012) we mainly use five measures: (1) The loss frequency; (2) the distribution of ROA, TACC, OPACC, and NOPACC; (3) the Market-to-Book ratio; (4) the asymmetric timeliness.

For unconditional conservatism, the ratio market-to-book (MTB) can be used to measure the level of understatement of book values over their market value. A value of one of MTB is an indicator of presence of unconditional conservatism (Felthman and Ohlson, 1995; Roychowdhury and Watts, 2007).

\section{Sample selection and variables measures:}

To analyze the time variation and cross-sectional differences in conservatism, we use data collected from companies belong to 47 emerging countries over the period from 2000 to 2012. Countries are selected from both emerging marke ts and frontier emerging markets following MSCI and Standard and Poor's classifications. The preliminary sample includes all firms from 47 emerging markets; however the unavailability of data for some variables had limited the number of countries to 37 countries. Countries are classified according to four regions: (i) Americas countries; (ii) Asia countries; (iii) MENA/Africa countries and (iv) East Europe countries. The initial sample contains 46223 firm-years observations. We exclude all firm-years with missing data for any variable used in the study. Besides, we eliminate financial firms from our analysis. In fact, some of used measures solely rely on accounting data (balance sheet, income statement) and financial firms report accounting numbers in different way from other firms. Therefore, our measures can be affected by these differences. In addition, we exclude firms with negative total assets. Indeed, the value of total assets is used as a deflator in measuring conservatism indicators (ROA, CFOA, TACC, OPACC and NOPACC). The negative value can biased our result interpretations. Furthermore the percentage of firms with negative total assets is negligible comparing to the whole sample. Thus eliminating them does not affect results. We also delete firms in the top and bottom $1 \%$ of earnings, cash flows, and accruals component to eliminate extreme values. The final sample contains 35,846 firm-years observations. The data for all variables are collected from Thomson Financial and Worldscope databases.

Consistent with Givoly and Hayn (2000), Ball and Shivakumar (2005) and Lai et al. (2012), the variable definitions and 
measurement are defined in Table 1.

Table 1: List of variables

\begin{tabular}{|c|c|c|}
\hline Variables & Abbreviation & Measures \\
\hline Return on asset & ROA & The ratio of net income-to-total assets \\
\hline Operating Accruals & OPACC & $\begin{array}{l}\text { The change non-cash current assets minus the change in current liabilities (excluding } \\
\text { short-term debt) deflated by total assets }\end{array}$ \\
\hline Non-operating Accruals & NOPACC & Difference between total accruals and operating accruals deflated by total assets \\
\hline Market-to-Book ratio & MTB & Ratio of market capitalization to book value of equity \\
\hline Size & Size & Natural logarithm of market capitalization \\
\hline Leverage & Lev & Total debt to market capitalization \\
\hline Annual stock return & RET & $\begin{array}{l}\text { calculated by cumulating monthly returns ending } 3 \text { months after the firm's fiscal year } \\
\text { end }\end{array}$ \\
\hline
\end{tabular}

\section{Time variation of conservatism:}

The first objective of our study is to examine the time-series behavior conservatism's measures over the period 2000 to 2012. We provide descriptive statistics on the different measures discussed above. We also report results by subdividing our 13 years of data into two sub-periods (2000-2007 and 2008-2012). This allows us to test differences between these two periods.

\subsection{Loss frequency and profitability:}

The first measure that we use to examine the time variation in conservatism is the loss frequency calculated each year by counting the number of firms that reported negative income divided by the total number of firms in that year. However, the profitability across firms is measured using the ROA ratio. Table 2 shows the loss frequency for all years between 2000 and 2012 and for the two sub-periods. Results show that the loss frequency has decreased from $21 \%$ in 2000 to $13 \%$ in 2007. However the loss frequency has increased from 13\% in 2007 to $17 \%$ in 2012 with peak in 2008 and 2009 to reach $20 \%$. The mean difference of loss frequency between the two sub-periods is positive and significant which means that the number of losses is greater in the period between 2007 and 2012 than in the period between 2000 and 2007. The profitability as measured by ROA ratio, exhibit the same pattern as for the loss frequency. In fact we observe an increase in the mean of ROA from 4.23 per cent in 2000 to 7.17 per cent in 2007 after that we observe a decline of ROA throughout the period from $7.17 \%$ in 2007 to 5\% in 2012. The difference in the mean of ROA is significant between the two sub-periods $(6.31 \%$ vs. $5.35 \%$ ). The median of ROA is lower than the mean, indicating that the distribution of ROA is left skewed. In conclusion and based on those measure we can say the level of accounting conservatism has decreased in the period between 2000 to 2007 and increased over the period 2007-2012.

Table 2: Distribution of Loss Frequency and profitability

\begin{tabular}{|c|c|c|c|c|c|c|c|c|c|}
\hline Year & $\begin{array}{l}\text { All Firms } \\
\text { (N) }\end{array}$ & Loss (N) & $\begin{array}{l}\text { Freq. of } \\
\text { losses }(\%)\end{array}$ & \multicolumn{2}{|c|}{ ROA } & Sub-periods & $\begin{array}{l}\text { Freq. of } \\
\text { losses }(\%)\end{array}$ & \multicolumn{2}{|r|}{ ROA } \\
\hline 2000 & 1038 & 218 & 21.00 & .0432 & .0410 & & & & \\
\hline 2002 & 1472 & 307 & 20.86 & .0485 & .0498 & & & & \\
\hline 2003 & 1809 & 295 & 16.31 & .0552 & .0526 & $2000-2007$ & 15.60 & .06313 & .0585 \\
\hline 2004 & 2075 & 307 & 14.80 & .0641 & .0612 & & & & \\
\hline 2005 & 2409 & 349 & 14.49 & .0667 & .0605 & & & & \\
\hline 2008 & 3299 & 681 & 20.64 & .0563 & .0546 & & & & \\
\hline
\end{tabular}




\begin{tabular}{lllllllll}
$\mathbf{2 0 0 9}$ & 3372 & 700 & 20.76 & .0515 & .0494 & Difference & 2.85 & -0.007 \\
$\mathbf{2 0 1 0}$ & 3587 & 612 & 17.06 & .0556 & .0515 & P-value & $(0.000)$ & $(0.000)$ \\
$\mathbf{2 0 1 1}$ & 4051 & 706 & 17.43 & .0555 & .0532 & & $(0.000)$ \\
$\mathbf{2 0 1 2}$ & 5262 & 911 & 17.31 & .0500 & .0476 & & \\
\hline
\end{tabular}

\subsection{Distribution of CFOA, TACC, OPACC and NOPACC}

\subsubsection{Mean and Median:}

The mean and median of cash flows from operations, total accruals, operating accruals and non-operating accruals are displayed in table 4. The first indicator presented in the Table 3 is the cash flows from operation to total assets (CFOA) ratio which reflects the firms' economic performance (Healy et al., 1992). According to the calculations, there is no obvious pattern over time. The result suggests that the increasing and the decreasing in the profitability observed in different periods are not related to the change in the distribution of cash flows from operation activities. The mean of TACC is negative in the 13-year period and most shifts in TACC come from NOPACC which also a negative mean over all years. The timeseries pattern of the median of TACC, NOPACC are similar to the behavior of mean. Also we remark that median of all variables are less than the mean, indicating that variables are left skewed. In detail, the mean of TACC was -3 percent of total assets in 2000 and become -1.43 per cent in 2007 however in 2008 this ratio takes the value of $-6.17 \%$ and -3.79 per cent in 2012. The mean of TACC has declined between the two periods, indeed the mean difference between the two subperiods is negative and significant at $1 \%$ level. We observe the same result for the NOPACC. This result shows that the decreasing of profitability during the period between 2007 and 2012 can be attributed to the distribution of accruals over the same period that is the difference between earnings and cash flows.

\subsubsection{Variance of CFOA, TACC, OACC, NOACC:}

The time series change in the variances of ROA, TACC, OPACC and NOPACC is displayed in Table 4. The variance of ROA is constant over all years of the study. However, the TACC variance has increased from 1.43 per cent in 2000 to 7.13 percent in 2012 and the NOAPCC variance has increased from 1.49 per cent in 2000 to 6.49 in per cent in 2012. Comparing the variance of TACC and NOPACC between the two sub-periods, we find that the variance was increased in the period of 2007-2009 comparing to the period of 2000-2007. The increase in the TACC and NOPACC variances can suggest that the conservatism has increased after 2007.

Table 3: Mean and median of cash flows from operations and accruals deflated by total assets

\begin{tabular}{|c|c|c|c|c|c|c|c|c|c|}
\hline \multirow[b]{2}{*}{ Year } & \multicolumn{5}{|c|}{ Mean } & \multicolumn{4}{|c|}{ Median } \\
\hline & $\mathrm{N}$ & CFOA & TACC & $\mathrm{OACC}$ & NOACC & CFOA & TACC & $\mathrm{OACC}$ & NOACC \\
\hline 2000 & 1038 & 0.0706 & -0.0300 & 0.0102 & -0.0402 & 0.0751 & -0.0402 & 0.0071 & -0.0508 \\
\hline 2001 & 1301 & 0.0777 & -0.0382 & 0.0091 & -0.0473 & 0.0690 & -0.0368 & -0.0039 & -0.0361 \\
\hline 2003 & 1809 & 0.0642 & -0.0249 & 0.0149 & -0.0398 & 0.0610 & -0.0188 & 0.0133 & -0.0380 \\
\hline 2004 & 2075 & 0.0643 & -0.0165 & 0.0203 & -0.0367 & 0.0716 & -0.0231 & 0.0089 & -0.0356 \\
\hline 2005 & 2409 & 0.0777 & -0.0272 & 0.0065 & -0.0337 & 0.0672 & -0.0189 & 0.0140 & -0.0391 \\
\hline 2007 & 3395 & 0.0666 & -0.0143 & 0.0274 & -0.0416 & 0.0914 & -0.0507 & 0.0079 & -0.0607 \\
\hline 2008 & 3299 & 0.0983 & -0.0617 & 0.0059 & -0.0677 & 0.0650 & -0.0298 & -0.0108 & -0.0172 \\
\hline 2009 & 3372 & 0.0687 & -0.0352 & -0.0192 & -0.0160 & 0.0522 & -0.0113 & 0.0203 & -0.0365 \\
\hline 2010 & 3587 & 0.0505 & -0.0101 & 0.0261 & -0.0361 & 0.0685 & -0.0266 & 0.0160 & -0.0468 \\
\hline 2011 & 4051 & 0.0704 & -0.0307 & 0.0183 & -0.0490 & 0.0704 & -0.0347 & 0.0070 & -0.0446 \\
\hline 2012 & 5262 & 0.0725 & -0.0379 & 0.0036 & -0.0415 & 0.0751 & -0.0402 & 0.0071 & -0.0508 \\
\hline P-value & & 0.9291 & 0.000 & 0.000 & 0.0060 & 0.0037 & 0.000 & 0.000 & 0.000 \\
\hline
\end{tabular}


Table 4: Variance of ROA, Cash flows and accruals

\begin{tabular}{lccccc}
\hline Year & Var(ROA) & Var(CFOA) & Var(TACC) & Var(OPACC) & Var(NOACC) \\
\hline $\mathbf{2 0 0 0}$ & 0.0044 & 0.0157 & 0.0143 & 0.0070 & 0.0149 \\
$\mathbf{2 0 0 1}$ & 0.0071 & 0.0156 & 0.0194 & 0.0081 & 0.0169 \\
$\mathbf{2 0 0 2}$ & 0.0063 & 0.0303 & 0.0351 & 0.0268 & 0.0112 \\
$\mathbf{2 0 0 3}$ & 0.0053 & 0.0102 & 0.0109 & 0.0058 & 0.0107 \\
$\mathbf{2 0 0 4}$ & 0.0073 & 0.0250 & 0.0208 & 0.0153 & 0.0254 \\
$\mathbf{2 0 0 5}$ & 0.0071 & 0.0141 & 0.0117 & 0.0156 & 0.0169 \\
$\mathbf{2 0 0 6}$ & 0.0073 & 0.0165 & 0.0139 & 0.0083 & 0.0125 \\
$\mathbf{2 0 0 7}$ & 0.0079 & 0.0148 & 0.0139 & 0.0094 & 0.0147 \\
$\mathbf{2 0 0 8}$ & 0.0089 & 0.0193 & 0.0181 & 0.0111 & 0.0165 \\
$\mathbf{2 0 0 9}$ & 0.0061 & 0.0194 & 0.0188 & 0.0137 & 0.0157 \\
$\mathbf{2 0 1 0}$ & 0.0057 & 0.0132 & 0.0119 & 0.0068 & 0.0106 \\
$\mathbf{2 0 1 1}$ & 0.0064 & 0.0267 & 0.0249 & 0.0190 & 0.0134 \\
$\mathbf{2 0 1 2}$ & 0.0046 & 0.0742 & 0.0713 & 0.0104 & 0.0694 \\
$\mathbf{2 0 0 0 - 2 0 0 7}$ & 0.0069 & 0.0173 & 0.0166 & 0.0119 & 0.0155 \\
$\mathbf{2 0 0 8}-2012$ & 0.0062 & 0.0347 & 0.0330 & 0.0124 & 0.0291 \\
Difference & -0.0007 & 0.0173 & 0.0164 & 0.1122 & 0.0136 \\
p-value & 1.000 & 0.000 & 0.000 & 0.0028 & 0.000 \\
\hline
\end{tabular}

\subsection{Market-to-Book Ratio (MTB):}

Our third measure is the market-to-book ratio. This index shows how much book value of equity is comparing to its market value. Recall that when conservatism is exercised, the MTB ratio should exceed the value of one. Figure 1 indicates the mean and the median of the MTB ratio. During the period between 2000 and 2007, the MTB mean has decreased from 1.6 in 2000 to 0.89 in 2007, however during the period of 2007-2012, the MTB ratio has increased in mean to reach the value of 1.07 with a peak in 2008 of 1.48. Overall, the MTB mean is significantly greater in the period 20007-2012 than the mean in the period 2000-2007. Those results confirm the remarks about the trend of conservatism. Again, according to MTB values, unconditional conservatism has increased since 2007 after a period of decreasing.

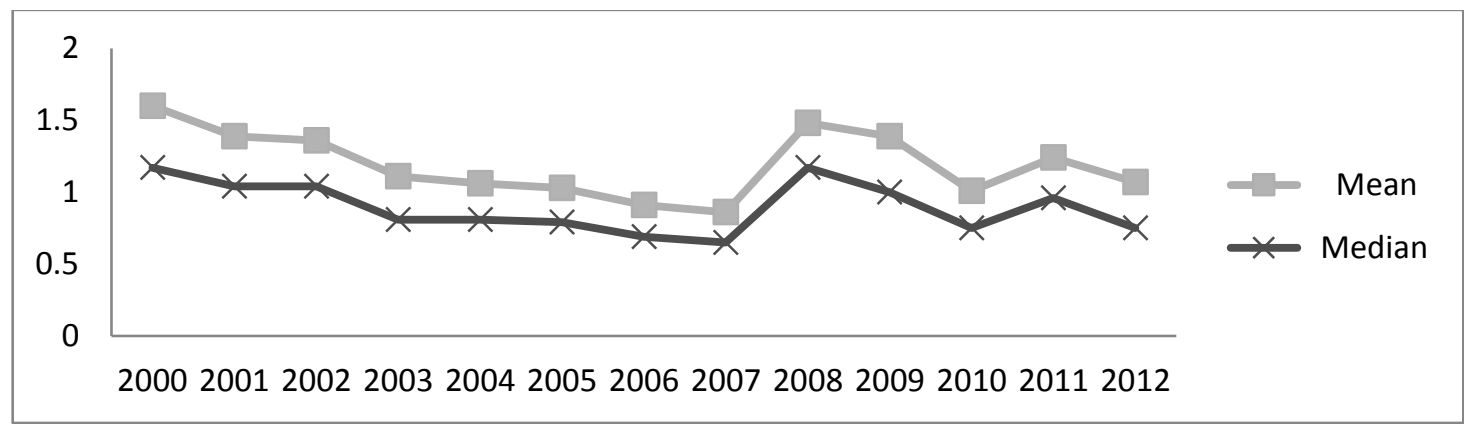

Figure 1: Meand and Median of MTB ratio

\subsection{Asymmetric timeliness:}

Table 6 shows the result of the annual regression estimation of the earning-return model presented above in equation (1). The estimations are made each year using all firms in all countries. Consistent with previous results in US, Europe and Australia, the first measure which is the asymmetric timeliness coefficient, is positive in all years. These results show that, in general, the financial reporting systems are conservative, indicating that bad news is recognized faster than good news. During the period between 2000 and 2012 the coefficient of asymmetric timeliness varies from year to year without any obvious trend. It ranges between 0.0192 and 0.2259 . 
Table 6: annual estimations of Asymmetric timeliness: Basu (1997) Model

\begin{tabular}{|c|c|c|c|c|c|c|}
\hline \multicolumn{7}{|c|}{$E A R_{i}=\beta_{0}+\beta_{1} D R_{i}+\beta_{2} R_{t}+\beta_{3} D R_{t} * R_{t}+\varepsilon_{t}$} \\
\hline Year & $\beta 0$ & $\beta 1$ & $\beta 2$ & $\beta 3$ & $\operatorname{Adj} R^{2}(\%)$ & $\mathrm{N}$ \\
\hline \multirow[t]{2}{*}{2000} & 0.0646 & 0.0250 & -0.0038 & 0.1015 & & \\
\hline & $(0.000)$ & $(0.040)$ & $(0.517)$ & $(0.000)$ & 5.04 & 1038 \\
\hline \multirow[t]{2}{*}{2001} & 0.0419 & -0.0373 & 0.0065 & 0.0636 & & \\
\hline & $(0.000)$ & $(0.011)$ & $(0.234)$ & $(0.103)$ & 2.56 & 1301 \\
\hline \multirow[t]{2}{*}{2002} & 0.0734 & -0.0158 & -0.0001 & 0.1166 & & \\
\hline & $(0.000)$ & $(0.158)$ & $(0.972)$ & $(0.000)$ & 5.34 & 1472 \\
\hline \multirow[t]{2}{*}{2003} & 0.0532 & -0.0478 & 0.0037 & 0.0699 & & \\
\hline & $(0.000)$ & $(0.005)$ & $(0.188)$ & $(0.175)$ & 1.27 & 1809 \\
\hline \multirow[t]{2}{*}{2004} & 0.0895 & -0.0008 & -0.0019 & 0.2259 & & \\
\hline & $(0.000)$ & $(0.919)$ & $(0.537)$ & $(0.000)$ & 11.35 & 2075 \\
\hline \multirow[t]{2}{*}{2005} & 0.0851 & -0.0404 & -0.0009 & 0.1375 & & \\
\hline & $(0.000)$ & $(0.000)$ & $(0.413)$ & $(0.000)$ & 7.82 & 2409 \\
\hline \multirow[t]{2}{*}{2006} & 0.0696 & -0.0151 & -0.0006 & 0.1277 & & \\
\hline & $(0.000)$ & $(0.063)$ & $(0.585)$ & $(0.000)$ & 3.07 & 3299 \\
\hline \multirow[t]{2}{*}{2007} & 0.0752 & -0.0091 & 0.0012 & 0.1339 & & \\
\hline & $(0.000)$ & $(0.143)$ & $(0.283)$ & $(0.000)$ & 5.42 & 3372 \\
\hline \multirow[t]{2}{*}{2008} & 0.0364 & 0.0078 & -0.00014 & 0.0192 & & \\
\hline & $(0.000)$ & $(0.325)$ & $(0.911)$ & $(0.003)$ & 0.20 & 3299 \\
\hline \multirow[t]{2}{*}{2009} & 0.0437 & -0.0799 & -0.00025 & 0.0819 & & \\
\hline & $(0.000)$ & $(0.000)$ & $(0.703)$ & $(0.055)$ & 1.38 & 3372 \\
\hline \multirow[t]{2}{*}{2010} & 0.0699 & -0.0207 & 0.00756 & 0.1293 & & \\
\hline & $(0.000)$ & $(0.003)$ & $(0.008)$ & $(0.000)$ & 4.78 & 3587 \\
\hline \multirow[t]{2}{*}{2011} & 0.0743 & -0.0185 & -0.0024 & 0.0994 & & \\
\hline & $(0.000)$ & $(0.001)$ & $(0.330)$ & $(0.000)$ & 4.87 & 4051 \\
\hline \multirow[t]{2}{*}{2012} & 0.0555 & -0.0154 & -0.0028 & 0.1199 & & \\
\hline & $(0.000)$ & $(0.001)$ & $(0.263)$ & $(0.000)$ & 4.83 & 5262 \\
\hline
\end{tabular}

\section{Differences in conservatism level across regions, countries and industries}

In this section we try to analysis cross-sectional differences in conservatism. To do so, we use the Basu's(1997) model. First, we compare the level of conservatism across regions and countries. Second we study the difference in conservatism level between industries.

\subsection{Differences in conservatism acrossrRegions and countries}

Table 7 reports time-series averages of the estimated annual coefficients and the average of the annual regressions' adjusted $R^{2}$ s estimation of the Basu (1997) model given in equation (1). The estimations are computed for each country classified in four regions: AMERICA, ASIA, EAST EUROPE and MENA/AFRICA. Panel A of table 7 gives the estimations of the Basu (1997) model using firms which belong to America region. Only the following countries were retained in the analysis: Argentina, Brazil, Chili, Colombia, Mexico and Peru. Following the results, the asymmetric timeliness coefficient, $\beta_{3}$, is negative for all countries except for Argentina where the coefficient is positive but not significant. Overall, countries in South America region do not exhibit conservatism in their financial reporting. In addition, the estimation of the model for the global region also shows that the asymmetric timeliness coefficient is negative.

Table 7: Panel A: Difference in accounting conservatism across country: AMERICAS region

\begin{tabular}{cccccccc}
\hline Countries & $\boldsymbol{\beta 0}$ & $\boldsymbol{\beta 1}$ & $\boldsymbol{\beta 2}$ & $\boldsymbol{\beta 3}$ & BASU $^{*}$ Adj R $^{\mathbf{2}}$ \\
\hline Argentina & 0.048 & 0.042 & 0.185 & 0.157 & 8.401 & 20.05 \\
& $(0.043)$ & $(0.418)$ & $(0.318)$ & $(0.628)$ & -0.066 & -3.760 & 51.16 \\
Brazil & 0.142 & -0.017 & -0.083 & $(0.312)$ & $(0.455)$ & & \\
& $(0.039)$ & $(0.829)$ & -0.000 & 0.043 & -0.293 & -16.537 & 18.85 \\
Chili & 0.069 & $(0.999)$ & $(0.039)$ & $(0.411)$ & & \\
& $(0.000)$ & 0.004 & 0.034 & 0.267 & 14.824 & 44.73 \\
\hline \multirow{2}{*}{ Colombia } & 0.095 & $(0.644)$ & $(0.678)$ & $(0.214)$ & & \\
\hline
\end{tabular}




\begin{tabular}{ccccccc}
\hline Mexico & -0.240 & 0.317 & 0.637 & -0.170 & -7.479 & 26.22 \\
& $(0.436)$ & $(0.314)$ & $(0.297)$ & $(0.804)$ & & \\
Peru & 0.069 & -0.084 & 0.045 & -0.344 & -19.259 & 31.85 \\
& $(0.041)$ & $(0.420)$ & $(0.231)$ & $(0.447)$ & & \\
\multirow{2}{*}{ AMERICAS } & 0.074 & -0.116 & 0.004 & -0.319 & -17.726 & 8.1 \\
& $(0.000)$ & $(0.237)$ & $(0.408)$ & $(0.477)$ & & \\
\hline
\end{tabular}

Panel B of table 7 displays the result of estimations for countries from Asia region. They include China, India, Korea, Sri Lanka, Malaysia, Pakistan, Philippine, Thailand, and Taiwan. The results show that in all countries, the asymmetric timeliness coefficient is positive and significant except India, Pakistan (positive coefficient but not significant), Sri Lanka (negative coefficient). Overall, the financial reporting systems in Asia countries are conservative. Indeed the coefficient of asymmetric timeliness estimated for the entire Asia region is positive $(0.1054)$ and significant ( $\mathrm{p}$-value $=0.000)$. We also remark that Thailand firms report more conservative earnings $\left(\beta 3=0.2129\right.$; $B A S U=11.993$ degrees; average adjusted $\mathrm{R}^{2}$ of $9.06 \%$ ) followed by Malaysia ( $\beta 3=0.196$; BASU=11.118 degrees; Average adjusted $\mathrm{R}^{2}$ of $8.81 \%$ ). However, China firms exhibit the less degree of conservatism ( $\beta 3=0.0512$; BASU $=2.928$ degrees; Average adjusted $\mathrm{R}^{2}$ of $7.21 \%$ ). The estimation results of the Basu's (1997) model for countries in Europe region are given in Table 7 Panel C. The model is estimated for firms belong to Greece, Hungry, Poland, Russia and Slovenia. According to the results, only firms in Greece report conservative financial statements. The coefficient $\beta 3$ is positive $(0.230)$ and significant ( $\mathrm{p}$-value $=0.076)$ at $10 \%$ level Despite this result, overall the coefficient $\beta 3$ for the entire region is positive $(0.270)$ and significant $(p$-value $=0.051)$ at $10 \%$ level.

We will turn our attention to the countries from MENA/Africa region. The results are exhibited in Table 8 Panel D. Only firms from South Africa (Africa region) have conservative reporting system. The coefficient $\beta 3$ is positive $(0.205$; BASU $=11.67$ degrees) and significant (p-value $=0.001)$ at $1 \%$ level. For countries in MENA region, only Israel presents a positive and significant coefficient ( $\beta 3=0.133$; BASU=7.57; Average Adj. $\mathrm{R}^{2}=16.74 \%$ ), however, for other countries (United Arab of Emirates; Qatar, Saudi Arabia and Turkey) the asymmetric timeliness coefficient $\beta 3$ is positive but not significant, and negative in Egypt, Jordan and Kuwait. Nevertheless, overall countries, the coefficient $\beta 3$ is positive $(0.223)$ and significant ( $p$-value $=0.014$ ) at 5\% level indicating that firms in MENA/Africa have conservative reporting systems in general.

Between the four regions, we find that firms from East Europe report more conservative earnings $(\beta 3=0.27$; BASU=15.04 degrees, Average Adj $\left.\mathrm{R}^{2}=13 \%\right)$ followed by MENA/Africa firms $(\beta 3=0.2236$; BASU=12.63 degrees; Average Adj. $\left.\mathrm{R}^{2}=9.12 \%\right)$ and Asia firms $\left(\beta 3=0.1054\right.$; BASU=6.02 degrees; Average Adj. $\left.\mathrm{R}^{2}=4.49 \%\right)$.

Table 7, Panel B: Difference in accounting conservatism across country: ASIA region

\begin{tabular}{|c|c|c|c|c|c|c|}
\hline Countries & $\beta 0$ & $\beta 1$ & $\beta 2$ & $\beta 3$ & BASU & $\operatorname{Adj} R^{2}$ \\
\hline China & $\begin{array}{c}0.042 \\
(0.001)\end{array}$ & $\begin{array}{l}-0.003 \\
(0.520)\end{array}$ & $\begin{array}{c}0.018 \\
(0.045)\end{array}$ & $\begin{array}{c}0.051 \\
(0.044)\end{array}$ & 2.928 & 7.21 \\
\hline India & $\begin{array}{c}0.069 \\
(0.000)\end{array}$ & $\begin{array}{l}-0.012 \\
(0.191)\end{array}$ & $\begin{array}{c}0.002 \\
(0.101)\end{array}$ & $\begin{array}{c}0.017 \\
(0.456)\end{array}$ & 1.013 & 1.47 \\
\hline Korea & $\begin{array}{c}0.077 \\
(0.000)\end{array}$ & $\begin{array}{l}-0.035 \\
(0.075)\end{array}$ & $\begin{array}{l}-0.009 \\
(0.034)\end{array}$ & $\begin{array}{c}0.160 \\
(0.000)\end{array}$ & 9.141 & 8.26 \\
\hline Sri Lanka & $\begin{array}{c}0.108 \\
(0.014)\end{array}$ & $\begin{array}{l}-0.034 \\
(0.525)\end{array}$ & $\begin{array}{l}-0.008 \\
(0.862)\end{array}$ & $\begin{array}{l}-0.195 \\
(0.602)\end{array}$ & -11.045 & --- \\
\hline Malysia & $\begin{array}{c}0.055 \\
(0.000)\end{array}$ & $\begin{array}{l}-0.014 \\
(0.383)\end{array}$ & $\begin{array}{l}-0.013 \\
(0.152)\end{array}$ & $\begin{array}{c}0.196 \\
(0.000)\end{array}$ & 11.118 & 8.81 \\
\hline Pakistan & $\begin{array}{c}0.106 \\
(0.000)\end{array}$ & $\begin{array}{c}0.021 \\
(0.186)\end{array}$ & $\begin{array}{c}0.084 \\
(0.322)\end{array}$ & $\begin{array}{c}0.075 \\
(0.516)\end{array}$ & 4.265 & 9.26 \\
\hline Philippine & $\begin{array}{c}0.072 \\
(0.000)\end{array}$ & $\begin{array}{r}-0.0001 \\
(0.996)\end{array}$ & $\begin{array}{c}0.017 \\
(0.263)\end{array}$ & $\begin{array}{c}0.096 \\
(0.072)\end{array}$ & 5.523 & 12.31 \\
\hline Thailand & $\begin{array}{c}0.067 \\
(0.000)\end{array}$ & $\begin{array}{l}-0.002 \\
(0.911)\end{array}$ & $\begin{array}{c}0.010 \\
(0.005)\end{array}$ & $\begin{array}{c}0.212 \\
(0.005)\end{array}$ & 11.993 & 9.06 \\
\hline Taiwan & $\begin{array}{c}0.053 \\
(0.000)\end{array}$ & $\begin{array}{l}-0.012 \\
(0.040)\end{array}$ & $\begin{array}{c}0.012 \\
(0.393)\end{array}$ & $\begin{array}{c}0.189 \\
(0.001)\end{array}$ & 10.681 & 10.63 \\
\hline ASIA & $\begin{array}{c}0.061 \\
(0.000)\end{array}$ & $\begin{array}{c}-0.021 \\
(-0.045)\end{array}$ & $\begin{array}{c}0.0003 \\
(-0.807)\end{array}$ & $\begin{array}{c}0.105 \\
(0.000)\end{array}$ & 6.016 & 4.49 \\
\hline
\end{tabular}

Table 7, Panel C: Difference in accounting conservatism across country: EUROPE region 


\begin{tabular}{|c|c|c|c|c|c|c|}
\hline Countries & $\beta 0$ & $\beta 1$ & $\beta 2$ & $\beta 3$ & BASU & $\operatorname{Adj} R^{2}$ \\
\hline \multirow[t]{2}{*}{ Greece } & 0.003 & 0.008 & 0.291 & 0.230 & 11.29 & 33.66 \\
\hline & $(0.971)$ & $(0.861)$ & $(0.377)$ & $(0.076)$ & & \\
\hline \multirow[t]{2}{*}{ Hungary } & 0.024 & -0.052 & 0.059 & 0.376 & 20.15 & 56.62 \\
\hline & $(0.591)$ & $(0.465)$ & $(0.567)$ & $(0.439)$ & & \\
\hline \multirow[t]{2}{*}{ Poland } & 0.050 & -0.054 & 0.047 & -0.030 & -1.73 & 31.74 \\
\hline & $(0.002)$ & $(0.250)$ & $(0.076)$ & $(0.759)$ & & \\
\hline \multirow[t]{2}{*}{ Russia } & 0.106 & 0.057 & -0.064 & 0.204 & 11.65 & 45.36 \\
\hline & $(0.032)$ & $(0.117)$ & $(0.475)$ & $(0.201)$ & & \\
\hline \multirow[t]{2}{*}{ Slovinia } & -0.076 & 0.127 & 0.460 & -0.014 & -0.67 & 60.33 \\
\hline & $(0.426)$ & $(0.257)$ & $(0.199)$ & $(0.966)$ & & \\
\hline \multirow[t]{2}{*}{ EAST EUROPE } & 0.042 & -0.017 & 0.016 & 0.270 & 15.04 & 13.00 \\
\hline & $(0.012)$ & $(0.563)$ & $(0.444)$ & $(0.051)$ & & \\
\hline
\end{tabular}

Table 7, Panel D: Difference in accounting conservatism across country: MENA/AFRICA

\begin{tabular}{|c|c|c|c|c|c|c|}
\hline Countries & $\beta 0$ & $\beta 1$ & $\beta 2$ & $\beta 3$ & BASU & $\operatorname{Adj} R^{2}$ \\
\hline United Ar Emirates & $\begin{array}{c}0.092 \\
(0.021)\end{array}$ & $\begin{array}{c}-0.032 \\
(0.550)\end{array}$ & $\begin{array}{c}0.076 \\
(0.355)\end{array}$ & $\begin{array}{c}0.039 \\
(0.286)\end{array}$ & 2.23 & 48.75 \\
\hline Egypt & $\begin{array}{c}0.113 \\
(0.000)\end{array}$ & $\begin{array}{l}-0.156 \\
(0.326)\end{array}$ & $\begin{array}{c}0.009 \\
(0.590)\end{array}$ & $\begin{array}{l}-0.710 \\
(0.412)\end{array}$ & -35.56 & $* * * * *$ \\
\hline Israel & $\begin{array}{c}0.031 \\
(0.097)\end{array}$ & $\begin{array}{c}-0.006 \\
(0.784)\end{array}$ & $\begin{array}{l}-0.013 \\
(0.663)\end{array}$ & $\begin{array}{c}0.133 \\
(0.107)\end{array}$ & 7.57 & 16.74 \\
\hline Jordan & $\begin{array}{c}0.071 \\
(0.000)\end{array}$ & $\begin{array}{l}-0.015 \\
(0.392)\end{array}$ & $\begin{array}{c}0.123 \\
(0.426)\end{array}$ & $\begin{array}{l}-0.033 \\
(0.848)\end{array}$ & -1.89 & 42.85 \\
\hline Kuwait & $\begin{array}{c}0.041 \\
(0.061)\end{array}$ & $\begin{array}{l}-0.008 \\
(0.833)\end{array}$ & $\begin{array}{c}0.089 \\
(0.004)\end{array}$ & $\begin{array}{l}-0.453 \\
(0.377)\end{array}$ & -25.07 & $* * * *$ \\
\hline Nigiria & $\begin{array}{c}0.044 \\
(0.057)\end{array}$ & $\begin{array}{c}0.005 \\
(0.853)\end{array}$ & $\begin{array}{c}0.102 \\
(0.090)\end{array}$ & $\begin{array}{l}-0.037 \\
(0.509)\end{array}$ & -2.10 & $* * * *$ \\
\hline Qatar & $\begin{array}{c}0.118 \\
(0.023)\end{array}$ & $\begin{array}{l}-0.013 \\
(0.792)\end{array}$ & $\begin{array}{l}-0.306 \\
(0.479)\end{array}$ & $\begin{array}{c}0.382 \\
(0.384)\end{array}$ & 21.34 & 29.46 \\
\hline Saudi Arabia & $\begin{array}{c}0.057 \\
(0.000)\end{array}$ & $\begin{array}{c}0.013 \\
(0.213)\end{array}$ & $\begin{array}{l}-0.005 \\
(0.761)\end{array}$ & $\begin{array}{c}0.140 \\
(0.132)\end{array}$ & 8.00 & 15.66 \\
\hline Turkey & $\begin{array}{c}0.080 \\
(0.000)\end{array}$ & $\begin{array}{c}-0.004 \\
(0.832)\end{array}$ & $\begin{array}{l}-0.020 \\
(0.234)\end{array}$ & $\begin{array}{c}0.293 \\
(0.227)\end{array}$ & 16.42 & 15.62 \\
\hline South Africa & $\begin{array}{c}0.109 \\
(0.000)\end{array}$ & $\begin{array}{l}-0.057 \\
(0.356)\end{array}$ & $\begin{array}{l}-0.031 \\
(0.244)\end{array}$ & $\begin{array}{c}0.205 \\
(0.001)\end{array}$ & 11.67 & 14.58 \\
\hline MENA/AFRICA & $\begin{array}{l}0.0820 \\
(0.000)\end{array}$ & $\begin{array}{l}-0.002 \\
(0.903)\end{array}$ & $\begin{array}{l}-0.010 \\
(0.246)\end{array}$ & $\begin{array}{c}0.223 \\
(0.014)\end{array}$ & 12.60 & 9.12 \\
\hline
\end{tabular}

\subsection{Difference in conservatism across industries:}

Table 8 reports the estimation results of the Basu's (1997) model by industries using the Fama-MacBeth method. The asymmetric timeliness coefficient $\beta 3$ is positive and significant for all industries except for OilandGas and Utilities sectors where the coefficient is positive but not significant. Among sectors where the coefficient $\beta 3$ is positive and significant, we find that Telecommunications sector is the more conservative $\left(\beta 3=0.395\right.$; $B A S U=22.34$ degrees; Average Adj. $\mathrm{R}^{2}=21.66 \%$ ) followed by ConsummerandServices Technology and Basic Materials sector. Consumer Goods is the less conservative sector $\left(\beta 3=0.0826\right.$; BASU=4.71 degrees; Average Adj. $\left.\mathrm{R}^{2}=4.27 \%\right)$.

Table 8: Annual cross-sectional Fama-MacBeth regressions of earnings regressed on returns by industries

\begin{tabular}{|c|c|c|c|c|c|c|c|}
\hline Industry & $\beta 0$ & $\beta 1$ & $\beta 2$ & $\beta 3$ & BASU & Adj $R^{2}$ & $\mathrm{~N}$ \\
\hline \multirow[t]{2}{*}{ OIl and Gas } & 0.1099 & -0.0343 & -0.0219 & 0.0450 & & & \\
\hline & $(0.0000)$ & $(0.2210)$ & $(0.3640)$ & $(0.2790)$ & 2.58 & 10.75 & 590 \\
\hline \multirow[t]{2}{*}{ Basic Materials } & 0.0710 & -0.0073 & 0.0061 & 0.1314 & & & \\
\hline & $(0.0000)$ & $(0.4480)$ & $(0.0040)$ & $(0.0000)$ & 7.47 & 6.76 & 5427 \\
\hline \multirow[t]{2}{*}{ Industrials } & 0.0659 & -0.0208 & -0.0004 & 0.113 & & & \\
\hline & $(0.0000)$ & $(0.0560)$ & $(0.7930)$ & $(0.0000)$ & 6.47 & 5.31 & 10929 \\
\hline \multirow[t]{2}{*}{ Consumer Goods } & 0.0632 & -0.0299 & 0.0007 & 0.0826 & & & \\
\hline & $(0.0000)$ & $(0.0020)$ & $(0.7370)$ & $(0.0040)$ & 4.71 & 4.27 & 8850 \\
\hline \multirow[t]{2}{*}{ Health Care } & 0.0748 & -0.0074 & -0.0058 & 0.1067 & & & \\
\hline & $(0.0000)$ & $(0.3000)$ & $(0.4970)$ & $(0.0010)$ & 6.09 & 6.43 & 1771 \\
\hline Consummer Services & 0.0572 & -0.0029 & -0.0007 & 0.1475 & 8.39 & 5.99 & 2959 \\
\hline
\end{tabular}




\begin{tabular}{|c|c|c|c|c|c|c|c|}
\hline \multirow{3}{*}{ Telecommunications } & $(0.0000)$ & $(0.7370)$ & $(0.8920)$ & $(0.0010)$ & \multirow[b]{3}{*}{22.34} & \multirow[b]{3}{*}{21.66} & \multirow[b]{3}{*}{411} \\
\hline & 0.0360 & 0.0288 & -0.2065 & 0.3950 & & & \\
\hline & $(0.1230)$ & $(0.3110)$ & $(0.3490)$ & $(0.0950)$ & & & \\
\hline \multirow[t]{2}{*}{ Utilities } & $\begin{array}{c}0.0926 \\
(0.0000)\end{array}$ & -0.0085 & -0.0069 & 0.3346 & \multirow[b]{2}{*}{18.54} & \multirow[b]{2}{*}{14.12} & \multirow[b]{2}{*}{1045} \\
\hline & & $(0.5840)$ & $(0.7330)$ & $(0.2350)$ & & & \\
\hline Technology & $\begin{array}{c}0.0433 \\
(0.0000)\end{array}$ & $\begin{array}{l}-0.0530 \\
(0.0830)\end{array}$ & $\begin{array}{l}-0.0180 \\
(0.1440)\end{array}$ & $\begin{array}{c}0.1194 \\
(0.0030)\end{array}$ & 6.82 & 7.21 & 3864 \\
\hline
\end{tabular}

\section{Conclusion:}

This paper examines the variation in time of conservatism in emerging countries over the period between 2000 and 2012. To do so, following Givoly and Hayn (2000) and Lai et al. (2012), we use five different measures to assess the pattern and the shift into the degree of conservatism over time. Overall, there is no obvious trend in the level of conservatism for the full period. However, we have observed that there mainly two patterns. The first one indicates a decrease of conservatism through the period between 2000 and 2007 and the second shows that finical reporting systems are become more conservative since 2007 until present day with a peak in 2012. The second objective of our paper was to examine differences in the level of conservatism across regions, countries, and industries and. We find that countries from East Europe are more conservative, followed by Asia countries and MENA/Africa firms. However, firms from America region produce non conservative financial statements. In addition, we find that firms belong to telecommunications sector has earnings that are more conservative than other sectors. Understanding the pattern and differences in conservatism level is important for financial statement analysis, standard setters, securities regulation, investors, firms and academic research. Our work is subject to some limitations. First, all the presented methods are subject to criticisms. For example, one of the limitations of Basu (1997) measure is that it depends on the association between return and market information and on how can return absorbs this information, this implies that the market is efficient which cannot be the case of emerging markets. In addition, in emerging markets financial statements are released several month after the closing date, therefore market return may reflect past performance that current earnings. We use different measures of conservatism to mitigate the weakness of some measures and to have a minimum of robustness of our results. Second, many countries have been eliminated from our analysis due to missing data which can affect our cross-section comparisons. Third, our study involves data gathered from many different countries with different institutional and culture factors which should be included in the analysis to more explain differences in our findings. Future research can be directed to examine the determinant factors of the change in the level of conservatism in time and across countries.

\section{References:}

Balkrishna, H. Coulton, J. J. and Taylor. S. L. (2007), “Accounting losses and earnings conservatism: evidence from Australian Generally Accepted Accounting Principles", Accounting and Finance, vol.47, No. 3, pp.381-400.

Ball, R. (2001), "Infrastructure requirements for an economically efficient system of public financial reporting and disclosure”. Brookings-Wharton Papers on Financial Services, pp. 127-169.

Ball, R. and Shivakumar, L. (2005), "Earnings quality in UK private firms: comparative loss recognition timeliness", Journal of Accounting and Economics, vol.39(1), pp. 83-128.

Ball, R. Kothari, S. P. and Robin, A. (2000), "The effect of international institutional factors on properties of accounting earnings", Journal of Accounting and Economics, vol.29, pp. 1-51.

Basu, S. (1997), "The conservatism principle and the asymmetric timeliness of earnings", Journal of Accounting and Economics, vol.24, pp. 3-37. Beaver, W. and Ryan, S. (2005), “Conditional and unconditional conservatism: concepts and modeling”, Review of Accounting Studies, vol. 10, 269-309. Chan, A. L., Lin, S.W.J. and Strong, N. (2009), “Accounting conservatism and the cost of equity capital: UK”, Managerial Finance, vol.35, pp. 325 - 345. Chen, Q., Hemmer, T. and Zhang, Y. (2007), "On the relation between conservatism in accounting standards and incentives for earnings management". Journal of Accounting Research, vol.45, pp.b541-565.

Cheng, L Meiting, L.and Yaowen, S. (2012), "Has Australian financial reporting become more conservative over time?", Accounting and Finance, vol.53, Issue 3, pp. 731-761.

Fan, Q. and Zhang, X. (2012), “Accounting conservatism, aggregation, and information quality”. Contemporary Accounting Research (forthcoming). Feltham, G. A. and Ohlson, J. A. (1995), "Valuation and clean surplus accounting for operating and financial activities”, Contemporary Accounting 
Gao, P. (2011), "A contracting approach to conservatism and earnings management". Working paper. University of Chicago.

Garcı'a Lara, J. M. and Mora, A. (2004), "Balance sheet versus earnings conservatism in Europe”, European Accounting Review, vol.13(2), pp. 261-292.

Garcia Lara, J., Garcia Osma, B., and Penalva, F. (2011), “Conditional conservatism and cost of capital”, Review of Accounting Studies, vol.16, pp. 247 271.

Gassen, J. Rolf, U. F. and Thorsten, S. (2013), "International differences in conditional conservatism - The role of unconditional conservatism and income smoothing”, European Accounting Review, vol.15, pp.527-564.

Giner, B. and Rees, W. (2001), "On the asymmetric recognition of good and bad news in France, Germany and the United Kingdom", Journal of Business Finance and Accounting, vol.28, pp. 1285 - 1331.

Givoly, D. and Hayn, C. (2000), “The changing time-series properties of earnings, cash flows and accruals: has financial reporting become more conservative?”, Journal of Accounting and Economics, vol. 29, pp. 287-320.

Grambovas, A. Giner, B. and Christodoulou, D. (2006), "Earnings conservatism panel data evidence from the European Union and the United States", Abacus, vol.42, pp. 354 - 378.

Guay, W., and Verrecchia, R. E. (2007), “Conservative disclosure”. Working paper. University of Pennsylvania.

Healy, P.M., Palepu, K.G. and Ruback, R.S. (1992), “Does corporate performance improve after mergers?,” Journal of Financial Economics, vol. 31,pp. $135-175$.

Khan, M. and Watts, R. (2009), "Estimation and empirical properties of a firm-year measure of accounting conservatism", Journal of Accounting and Economics, vol. 48, pp.132-150.

LaFond, R. and Roychowdhury, S. (2007), “Managerial ownership and accounting conservatism”, Journal of Accounting Research , vol. 46, pp.101-135. Mason, L. (2004), "The Impact of Accounting Conservatism on the Magnitude of the Differential Information Content of Cash Flows and Accruals", Journal of Accounting, Auditing and Finance, vol.19, pp. 249-282.

Pope, P. E. and Walker, M. (2003), "Ex-ante and ex-post accounting conservatism, asset recognition and asymmetric earnings timeliness", Working Paper, Lancaster University/University of Manchester.

Raonic, I. McLeay, S. and Asimakopoulos, I. (2004), "The timeliness of income recognition by European companies: an analysis of institutional and market complexity", Journal of Business Finance and Accounting, vol.31 (1), pp. 115-148.

Richardson, G. and Tinaikar, S. (2004), “Accounting based valuation models: what have we learned?”, Accounting and Finance, vol. 44(2), pp. 223-255. Roychowdhury, S. and Watts, R. (2007), “Asymmetric timeliness of earnings, market-tobook and conservatism in financial reporting”, Journal of Accounting and Economics, vol. 44,pp. 2-31.

Roychowdhury, S. and Watts, R. (2007). "Asymmetric timeliness of earnings, market-to-book and conservatism in financial reporting”, Journal of Accounting and Economics, vol. 44,pp. 2-31.

Watts, R.L. (2003a), “Conservatism in accounting part I: Explanations and implications”. Accounting Horizons, vol.17, pp. 207-221.

Watts, R.L. (2003b), Conservatism in accounting part II: Evidence and research opportunities. Accounting Horizons, vol.17, pp. $287-301$. 